\title{
Vergiye Gönüllü Uyumu Etkileyen Faktörlerin Lojistik Regresyon Analizi ile Belirlenmesi
}

Gülin TABAKAN (https://orcid.org/0000-0002-4053-8687), Department of Public Finance, Aksaray University, Turkey; e-mail: gtabakan@aksaray.edu.tr

Orçun AVCI (https://orcid.org/0000-0002-7917-9802), Department of Public Finance, Aksaray University, Turkey; e-mail: orcun.avci@outlook.com

\section{Determination of Variables Affecting Voluntary Tax Compliance by Using Logistic Regression Analysis}

\begin{abstract}
The most important tool for states to increase tax revenues for their increasing expenditure is to maintain voluntary tax compliance. At this point, measuring voluntary tax compliance is significantly essential. In line with this importance, the purpose of the study is to determine the factors that affect taxpayers' voluntary tax compliance. For this purpose, logistic regression analysis is used in the study. According to the results, the variables of reference groups, tax amnesty, tax rates, remorse, tax audit, religious sensitivity, and tax information have statistically significant effects on taxpayers' voluntary tax compliance. Tax penalties, efficiency, and fairness of tax administration, and income variables do not have a statistically significant effect.

Keywords : Tax, Voluntary Tax Compliance, Logistic Regression Analysis.

JEL Classification Codes: $\mathrm{H} 20, \mathrm{H} 29, \mathrm{C} 13$.

\section{$\ddot{\mathbf{O} z}$}

Devletlerin artan ihtiyaçları neticesinde vergi gelirlerini arttırabilmesinin en önemli aracı vergiye gönüllü uyumun sağlanmasıdır. Bu noktada vergiye gönüllü uyumun ölçülmesi büyük önem arz etmektedir. Söz konusu önem doğrultusunda çalışmanın amac1, mükelleflerin vergiye gönüllü uyumu üzerinde etkili olan faktörlerin belirlenmesidir. Bu amaçla çalışmada lojistik regresyon analizi kullanılmıştır. Elde edilen sonuçlara göre; referans grupları, vergi affı, vergi oranları, vicdan azabı, vergi denetimi, dini duyarlılık ve vergi bilgisi değişkenlerinin mükelleflerin vergiye gönüllü uyumu üzerinde istatistiksel olarak anlamlı bir etkisi varken; vergi cezaları, vergi idaresinin etkinliği ve adaleti ile gelir değişkenlerinin ise istatistiksel olarak anlamlı bir etkisi bulunmamıştır.
\end{abstract}

Anahtar Sözcükler $\quad$ : Vergi, Vergiye Gönüllü Uyum, Lojistik Regresyon Analizi. 


\section{Giriş}

Vergiler, en önemli kamusal finansman kaynağı olması sebebiyle her zaman maliye teorisyenlerinin ve hükümetlerin odak noktasında olmaktadır. Bu noktada vergilendirmede rasyonalitenin sağlanabilmesi için gerek devlet gerekse mükellefler açısından uygun bir vergi politikasının uygulanması büyük önem arz etmektedir. Mükelleflerin herhangi bir zorlamaya gerek kalmadan kanunlara uygun hareket ederek, vergilerini ödemeleri birçok devletin yegâne arzusudur. Mükelleflerin vergiye gönüllü uyum sağlaması konusu günümüzde önemli olduğu gibi gelecekte de önemini koruyacaktır. Bunun en büyük sebebi gönüllü uyumun düşük olması sorununun tamamen bitmeyecek olmasıdır. 1990'lı yıllardan itibaren mükelleflerin vergileri gönüllü ödeme/ödememe üzerinde etkili olan faktörleri ele alan çalışmalar literatür kapsamında ağırlık kazanmaya başlamıştır. Ayrıca, vergiye gönüllü uyum konusunda disiplinlerarası çalışmaların ağırlık kazandığı da gözlemlenmektedir. Konunun birçok disiplini içeriğinde barındırması, bunun en temel sebebidir.

Çalışmanın amacı, mükelleflerin vergiye gönüllü uyumuna etki eden faktörlerin tespit edilmesidir. Çalışma kapsamında ilk olarak vergiye gönüllü uyumun kavramsal çerçevesi ve gönüllü uyumu etkileyen faktörler ele alınmıştır. Ayrıca, konu ile ilgili literatür taramasına yer verilerek ampirik çalışmalara değinilmiştir. Daha sonra ise; araştırmanın metodolojisi, ampirik bulgular ve sonuçlar değerlendirilmiştir. Çalışmanın örneklemini Adana ilinde bulunan 743 vergi mükellefi oluşturmaktadır. Çalışmada bağımlı değişken olarak gönüllü uyum alınmıştır. Bağımsız değişkenler ise; referans grup, vergi affı, vergi cezalar1, vergi oranları, vergi idaresinin etkinliği ve adaleti, vicdan azabı, denetim, gelir, dini duyarlılık ve vergi bilgisidir. Lojistik regresyon analizi yapılan çalışmada, mükelleflerin anket sorularına verdikleri cevaplar analize tâbi tutularak, çıkan sonuçlar değerlendirilmiş ve çözüm önerilerinde bulunulmuştur. Bu çalışmada vergiye gönüllü uyumu etkileyen faktörler açısından gerek kullanılan analiz gerekse faktörlere daha geniş bir perspektiften bakılmasından dolayı literatüre katkı sağlanması hedeflenmektedir.

\section{Vergiye Gönüllü Uyum ve Etkileyen Faktörler}

Küresel ekonomi ile birlikte elektronik ticaret gibi konuların gündeme gelmesi ve devletin küçülmesi beraberinde vergiye gönüllü uyum konusunun önem kazanmasını getirmiştir. Birçok gelir idaresinin karşılaştı̆̆ı sorunlardan biri, vergiye gönüllü uyum konusudur. Vergiye gönüllü uyum kavramından önce vergi uyumu kavramını açıklamakta fayda bulunmaktadır. En genel tanımıyla vergi uyumu, vergi mükelleflerinin vergi kanunlarına uyma derecesi şeklinde ifade edilebilir (James \& Alley, 2004: 29).

Mükelleflerin, vergisel yükümlülüklerini doğru ve zamanında yerine getirmeleri halinde vergi uyumu gerçekleşmektedir. Günümüzde bireylerin vergiye uyumu/vergi kaçırmamaları iyi bir vatandaşlık göstergesi olarak kabul edilmektedir (Yurdadoğ vd., 2016: 806). Vergi uyumu, kendi içerisinde gönüllü vergi uyumu ve zorla vergi uyumu şeklinde ikiye ayrılmaktadır. Vergiye olan uyumun en ideali mükelleflerin kendi iradesiyle gönüllü uyumu gerçekleştirmesidir. Gönüllü vergi uyumu, baskı ve ceza olmaksızın mükelleflerin 
Tabakan, G. \& O. Avc1 (2021), "Vergiye Gönüllü Uyumu Etkileyen Faktörlerin Lojistik Regresyon Analizi ile Belirlenmesi”, Sosyoekonomi, 29(48), 541-561.

vergi otoritesine duyduğu güven çerçevesinde yapmış oldukları vergi ödemelerini ifade etmektedir. Zorla vergi uyumundan kastedilen ise, vergi incelemesi vb. yollarla vergi denetimine maruz kalan mükelleflerin cezalar ile birlikte vergi ödemelerini gerçekleştirmesidir.

Vergiye gönüllü uyum ile vergi ödeyenlerin, vergi ödeme konusundaki çabaları ifade edilmektedir. Vergiye gönüllü uyum sağlamayan mükelleflerin tepki göstermeleri beklenen bir davranıştır. Vergi teorisinde bu durum verginin yansıması, vergi kayıp ve kaçağı şeklinde ortaya konan tepkiye isabet etmektedir. Bu bağlamda vergiye gönüllü uyum; vergi bilinci, vergi etiği ve vergi ahlakını belirli bir ölçüde yönlendiren şemsiye bir kavram olarak ifade edilebilmektedir. Vergi bilinci konusunda yapılan çalışmalar vergiler kadar eski olmasına rağmen, ödenen vergilerin verimli harcanması, kamu hizmetlerinin düzeyi ve etkinliği ile mükelleflerin bunlardan faydalanma konusundaki algılarının bilinç düzeyi, vergi etiği tartışmaları ve vergi ahlakının mükelleflerin vergiye gönüllü uyumu üzerinde oldukça önemli bir yeri olduğu açıktır (Erdem vd., 2020: 280). Bu bağlamda tüm ülkeler vergi sistemlerinde gönüllü vergi uyumunun sağlanmasını nihai hedef olarak görmektedir.

Gerek vergi otoritelerinin gücü gerekse de vergi otoritelerine duyulan güven, gönüllü vergi uyumunu sağlamak için büyük önem arz etmektedir. Güç ile güven arasındaki etkileşim hayati bir rol oynamaktadır. Bu bağlamda ele alınan konu; denetim olasılığı, bilgi, tutum, norm ve adalet gibi faktörler göz önünde bulundurularak, güç ve güven ekseninde gözden geçirilmeli ve tartış1lmalıdır (Kirchler vd., 2008: 210). Ancak, vergi otoritelerinin herhangi bir faaliyetinin vergiye gönüllü uyum üzerindeki etkisini tam manasiyla belirlemek oldukça güçtür. İnsan faktörü olması sebebiyle değişkenlik göstermesi beklenmektedir (Plumley, 2002: 355).

Vergiye gönüllü uyum konusunda literatür incelendiğinde, benzer mali sisteme sahip birçok ülkenin farklı vergi uyumu deneyimleri olduğu görülmektedir. Konuya ilişkin sonuçlar şu şekildedir: (1) Vergi kaçakçılığını ahlaksızlık olarak görme eğiliminde olan bireylerde, (2) mükelleflere etik değerler kazandırıldığında, (3) arkadaşları vergisini düzenli ödeyen bireylerde, (4) daha güçlü bir sosyal bağ duygusu olan toplumlarda vergiye gönüllü uyum daha fazla olabilmektedir (Torgler, 2002: 664). Çağdaş devlet anlayışının bir sonucu olarak, mükelleflerin gönüllü uyumunun sağlanması, hizmet kalitesinin arttırılması ve mükelleflerin beklentilerinin belirlenmesi gelir idarelerinin temel görevi durumuna dönüşmüştür. Günümüzde birçok gelir idaresi için önemli bir hale gelen gönüllü uyum; mükelleflerin, gelirlerini beyan edip vergilerini eksiksiz ve zamanında ödemeleri, diğer bir ifadeyle vergi ile ilgili yükümlülüklerini gönüllü, severek ve isteyerek yerine getirmeleri biçiminde açıklanabilir (GİB, 2007: 41).

Vergiye gönüllü uyumun sağlanamaması sorunu, vergiler kadar eski bir konudur. Bu süreçte yer alan faktörleri tanımlamak ve açıklamak, birçok dünya ülkesinin ilgisini çekmektedir (Andreoni vd., 1998: 818). Gönüllü vergi uyumunun temellerinin herhangi bir vergi uyum çalışması yapılmadan, kendiliğinden oluştuğu dönem olarak karşımıza Antik Yunan toplumu çıkmaktadır (Dolbun, 2019: 47). 
Günümüzde ise, vergiye gönüllü uyum mükellefler açısından kendiliğinden oluşmamaktadır. Vergiye gönüllü uyumu etkileyen faktörler konusunda yapılan çalışmalar uyum üzerinde etkili olacaktır. Vergi idaresi tarafından mükelleflerin vergiye gönüllü uyumunu sağlamada vergi idaresinin tarafsız, profesyonel ve adil yaklaşımı büyük önem arz etmektedir (GİB, 2007: 43). Mükelleflerin vergi ödeme konusunda isteksiz davranmalarının altında yatan sebepleri araştırmak, onların vergi kaçırma isteklerini azaltabilecek hususlara ilişkin birtakım önlemler alınmasını sağlayabilecek ve mükellefler daha gerçekçi beyanda bulunabileceklerdir (Akbulut, 2003: 93).

Vergiye gönüllü uyumu, içsel ve dişsal faktörler olmak üzere iki şekilde değerlendirmek mümkündür. İçsel faktörler; mükelleflerin neyin doğru, kabul edilebilir ve ahlaki bir davranış olacağına dair kendi algılamaları ışığında gerçekleştirdikleri yargısıdır. Dışsal faktörler; mükelleflerin vergilerin ödenmesi, kamu hizmetlerinin yapılması, devlet kararlarının sorumluluk düzeyi gibi alanlarda, devlet tarafindan nasıl bir muamele gördüklerine dair yargılarından oluşmaktadır (Torgler, 2004: 18).

Mükelleflerin vergiye gönüllü uyum göstermelerinde etkili olan faktörlerden biri referans gruplarıdır. Referans grubu, "kişinin belirli bir durumda davranışını belirlerken rehber olarak aldı̆̆ı, gözlemlediğ $i$ ve önem verdiği gruplardır. Bu grupların bazıları kişilerin davranışları üzerinde diğerlerinden daha fazla etkili” olabilmektedir (Arl1, 2012: 157). Buna göre referans grubu, kişilerin ait olduğu, bireyin kendine yakın hissettiği arkadaşları, meslektaşları, aile fertleri vb.'nden oluşmaktadır. Mükelleflerin vergiye gönüllü uyumunu etkilemesi bakımından referans grupları içerisindeki iletişimleri büyük önem arz etmektedir.

Song ve Yarbrough'un (1978) vergi uyumu davranış modeline göre, mükelleflerin vergilerini kendilerinin beyan etmesi ve ödemesini içeren gönüllü vergi uyumu üç ana faktör altında incelenir. Bu faktörler; genel yasal çerçeve, vatandaşların vergi ahlakı ile belirli bir zaman ve yerde faaliyet gösteren diğer durumsal faktörlerdir. Yasal çerçeve, “(1) yasaların meşruiyeti, (2) yasaların uygulanma sürecinin etkinliği ve (3) vatandaşların yasal yükümlülüklerini anlamass ve kabul etmesi ile şekillenmektedir”. Gönüllü vergi uyumunu kolaylaştıran veya engelleyen diğer durumsal faktörler arasında ise vergi oranı, işsizlik oranı, gelir düzeyi ve vergi idaresinin etkinliği sayılabilir (Song \& Yarbrough, 1978: 444).

Vergiye gönüllü uyumu etkileyen faktörler, çok çeşitli olup ülkeden ülkeye farklılık göstermekle birlikte, mükellefin gelir düzeyi, uygulanmakta olan vergi oranları, uyumsuzluk halinde uygulanacak müeyyideler ve denetim olasılığı, vergi idaresinin etkinliği, vergi sisteminin karmaşıklığı, toplumdaki vergi bilinci ve en nihayetinde vergi afları şeklinde sıralanabilir. Bu kapsamda vergiye gönüllü uyum; ekonomik, mali, sosyal ve psikolojik yönleri olan çok boyutlu bir yapıya sahiptir (Kumluca, 2003: 92).

Vergiye gönüllü uyumu etkileyen en önemli faktörler, ekonomik ve mali faktörlerdir. Bu kapsamda verginin konusu ve bireylerin ödeme gücü; mükelleflerin "vergi yükü"nü hissetme derecelerinde oldukça önem arz etmektedir. Ancak teorik ve ampirik araştırmaların 
artması neticesinde diğer faktörlerin önemi de anlaşılmıştır (Aktan \& Çoban, 2012: 200). Mükelleflerin vergi bilgisi anlamında mevzuata hâkim olma derecesi de oldukça önemlidir. Vergi mevzuatının karmaşık yapısı ve kendine özgü hukuk dili sebebiyle, konu hakkında uzman olmayan kişilerin anlaması oldukça güçtür. Bu durum da vergiye gönüllü uyum üzerinde negatif bir etki doğurabilmektedir.

Şüphesiz vergiye gönüllü uyumun gerçekleştiği bir ülkede ekonomik kararlar daha optimal olacaktır. Ayrıca, öngörüler daha sağlam gerçekleşebilecektir. Vergiye gönüllü uyumun vergi sistemindeki olumlu etkileri (Türkay, 2019: 173):

- "Vergi gelirlerinde artış ve denetim maliyetinde azalma,

- Idare ve mükellef arasında hoşgörü ve güven ortamı,

- Haksız rekabet ortamının engellenmesi,

- Vergi konularının ve oranlarının gelir gruplart ve sektörlere göre adil dağılımının săglanması (ücretliler ve tüketim vergilerindeki artışın önlenmesi) olarak" sayılabilir.

\section{Literatür}

Literatürde vergiye gönüllü uyumu etkileyen faktörlerin tespiti konusunda yapılmış birçok çalışma vardır. Vergiye gönüllü uyum üzerinde çok fazla faktörün etkili olması sebebiyle çalışmalardan elde edilen bulgular farklılık göstermektedir. Palil vd. (2013) ile Mohdali \& Pope'nin (2014) çalışmalarında diğer faktörlere göre dini faktörün vergiye gönüllü uyum üzerinde daha etkili olduğu sonucuna varılırken, Lemoine \& Roland-Levy (2013), Sigle vd. (2018), Ömür \& Bellikli (2019) ve Djajanti’nin (2020) çalışmalarında kamu otoritesine duyulan güvenin vergiye gönüllü uyum üzerinde daha çok etkili olduğu tespit edilmiştir. Tablo 1'de vergiye gönüllü uyumu etkileyen faktörler üzerine yapılan çalışmaların özeti sunulmuştur.

Tablo: 1

\section{Literatür Taraması}

\begin{tabular}{|c|c|c|c|}
\hline Yazar(lar) & Örneklem & Yöntem & Bulgular \\
\hline $\begin{array}{c}\text { Tuay \& } \\
\text { Güvenç } \\
(2007)\end{array}$ & $\begin{array}{l}\text { Türkiye'den } \\
18 \text { il }\end{array}$ & $\begin{array}{l}\text { Faktör analizi, } \\
\text { tek ve çift yönlü } \\
\text { varyans analizi }\end{array}$ & $\begin{array}{l}\text { Çalışmadan elde edilen sonuçlar daha önce yapılmış ampirik çalışmalarla paraleldir. } \\
\text { Çalışmada Türkiye'de vergiye gönüllü uyumun istenildiği gibi sağlanamadığı sonucuna } \\
\text { varılmıştır. }\end{array}$ \\
\hline $\begin{array}{l}\text { Gürler- } \\
\text { Hazman } \\
(2009)\end{array}$ & $\begin{array}{l}\text { Afyonkarah } \\
\text { isar- } \\
\text { Türkiye }\end{array}$ & $\begin{array}{l}\text { Lojistik regresyon } \\
\text { analizi }\end{array}$ & $\begin{array}{l}\text { Çalışma neticesinde vergiye gönüllü uyumu etkileyen faktörler bilindiği takdirde, devletin } \\
\text { tedbirler almasının kolaylaşacağı tespit edilmiştir. Politik başarısızlığın, şeffaflığın tam olarak } \\
\text { sağlanamamasının, kamusal mal ve hizmet sunumunun yetersizliğinin vergiye gönüllü uyum } \\
\text { üzerinde negatif etkisi olduğu sonucuna ulaşılmıştır. }\end{array}$ \\
\hline $\begin{array}{l}\text { İpek \& } \\
\text { Kaynar } \\
(2009)\end{array}$ & $\begin{array}{l}\text { Çanakkale- } \\
\text { Türkiye }\end{array}$ & $\begin{array}{l}\text { Mann-Whitney U } \\
\text { testi ve Kruskal- } \\
\text { Wallis H testi }\end{array}$ & $\begin{array}{l}\text { Elde edilen bulgulara göre vergiye gönüllü uyum, bireysel ve çevresel birtakım faktörlerden } \\
\text { etkilenmektedir. Yaş ilerledikçe vergiye gönüllü uyumun azaldığ1 tespit edilmiştir. }\end{array}$ \\
\hline $\begin{array}{l}\mathrm{Niu} \\
(2011)\end{array}$ & $\begin{array}{l}\text { New York- } \\
\text { ABD }\end{array}$ & $\begin{array}{l}\text { En küçük kareler } \\
\text { yöntemi ve zaman } \\
\text { serisi yatay kesit } \\
\text { analizi }\end{array}$ & $\begin{array}{l}\text { Çalışmanın neticesinde vergiye gönüllü uyumu etkileyen faktörlerden en önemlisinin vergi } \\
\text { denetimi olduğu sonucuna ulaşılmış ve aralarında pozitif yönlü bir ilişki tespit edilmiştir. }\end{array}$ \\
\hline $\begin{array}{l}\text { Garcia- } \\
\text { Valinas vd. } \\
\text { (2012) }\end{array}$ & $\begin{array}{l}\text { Doğu ve } \\
\text { Batı } \\
\text { Avrupa'dan } \\
32 \text { Ülke }\end{array}$ & Probit analizi & $\begin{array}{l}\text { Çalışma neticesinde, çevresel sosyal normlar ile çevre organizasyonlarının vergiye gönüllü } \\
\text { uyum ile pozitif ilişki içinde olduğu tespit edilmiştir. Bu ampirik bulguların yalnızca çevresel } \\
\text { meseleler bağlamında yararlı olmakla kalmayıp aynı zamanda kamu mallarının tedariği gibi } \\
\text { gönüllü uyumun daha genel araştırılacağı konulara da yararlı olacağı üzerinde durulmuştur. }\end{array}$ \\
\hline
\end{tabular}


Tabakan, G. \& O. Avcı (2021), "Vergiye Gönüllü Uyumu Etkileyen Faktörlerin

Lojistik Regresyon Analizi ile Belirlenmesi”, Sosyoekonomi, 29(48), 541-561.

\begin{tabular}{|c|c|c|c|}
\hline $\begin{array}{l}\text { Lemoine \& } \\
\text { Roland-Levy } \\
\text { (2013) }\end{array}$ & Fransa & Çok değişkenli analiz & $\begin{array}{l}\text { Yüksek güven düzeyinde olanların vergiye gönüllü uyumu diğerlerinden daha yüksek ve } \\
\text { istatistiksel olarak anlamlı çımıştır. Ayrıca kadınların erkeklerden daha fazla vergiye gönüllü } \\
\text { uyum sağladığı tespit edilmiştir. Sonuçlar kaygan yamaç modeli öngörülerini } \\
\text { doğrulamaktadır. }\end{array}$ \\
\hline $\begin{array}{l}\text { Palil vd. } \\
\text { (2013) }\end{array}$ & Malezya & $\begin{array}{l}\text { Pearson korelasyon } \\
\text { analizi ve hiyerarşik } \\
\text { regresyon analizi }\end{array}$ & $\begin{array}{l}\text { Elde edilen bulgulara göre katılımcıların vergiye gönüllü uyumlarının, eğitimlerine ve vergiye } \\
\text { ilişkin bilgilerine kıyasla düşük olduğu tespit edilmiştir. Ayrıca dini faktörlerin mükelleflerin } \\
\text { vergiye gönüllü uyumu üzerinde önemli bir rol oynadığı sonucuna varılmıștır. }\end{array}$ \\
\hline $\begin{array}{l}\text { Mohdali \& } \\
\text { Pope (2014) }\end{array}$ & Malezya & $\begin{array}{l}\text { Tek yönlü ANOVA } \\
\text { testi }\end{array}$ & $\begin{array}{l}\text { Çalıssma neticesinde dini faktörlerin vergiye gönüllü uyum üzerinde istatistiksel olarak } \\
\text { anlamlı ve pozitif etkisinin olduğu sonucuna varılmıştır. }\end{array}$ \\
\hline $\begin{array}{l}\text { Serim } \\
(2015)\end{array}$ & $\begin{array}{l}\text { İstanbul- } \\
\text { Türkiye }\end{array}$ & Siralı probit model & $\begin{array}{l}\text { Araştırma neticesinde toplanan vergilerin harcandığ } 1 \text { alanların bilindiği ve konuyla ilgili } \\
\text { beklentilerin örtüşmesi halinde, mükelleflerin gönüllü uyumunun arttı̆̆ sonucuna varılmıştır. } \\
\text { Vergi otoritesinin izlediği prosedürlerde adaletten daha az memnun olan mükelleflerin, } \\
\text { idarenin meşruiyetini sorgulayarak otoriteye karşı direnç gösterdiği gözlemlenmiştir. Ayrıca } \\
\text { mükelleflerin arkadaş ve aile çevresinin, vergi sistemine dürüstçe katkıda bulunmasını teşvik } \\
\text { etme hususunda önemli bir etkiye sahip olduğu kanısına varılmıstır. }\end{array}$ \\
\hline $\begin{array}{l}\text { Deyganto } \\
\text { (2018) }\end{array}$ & $\begin{array}{l}\text { Güney } \\
\text { Etiyopya }\end{array}$ & $\begin{array}{l}\text { İkili lojistik regresyon } \\
\text { analizi }\end{array}$ & $\begin{array}{l}\text { Çalışma neticesinde; cinsiyet, yaş, vergi bilgisi eksikliği, vergi sisteminin basitliği, ceza } \\
\text { bilinci, denetim olasılı̆̆ ve vergi algısı değişkenlerinin vergiye gönüllü uyum üzerinde etkili } \\
\text { olan temel faktörler olduğu tespit edilmiştir. Eğitim, vergi otoritesinin etkinliği, referans grup, } \\
\text { meslek, mükelleflerin gelir düzeyi ve adalet değişkenlerinin vergiye gönüllü uyum üzerinde } \\
\text { önemli bir etkisinin olmadığı tespit edilmiștir. }\end{array}$ \\
\hline $\begin{array}{l}\text { Sigle vd. } \\
\text { (2018) }\end{array}$ & Hollanda & $\begin{array}{l}\text { Doğrulayıcı faktör } \\
\text { analizi }\end{array}$ & $\begin{array}{l}\text { Elde edilen bulgulara göre kamu otoritesine duyulan güven ile mükelleflerin vergiye gönüllü } \\
\text { uyumu arasında pozitif bir ilişki olduğu ortaya konmuştur. Buna karşıı kamu otoritesinin } \\
\text { gücü ile zorla uyum arasında anlamlı bir ilișki olmadığ tespit edilmiștir. }\end{array}$ \\
\hline $\begin{array}{l}\text { Ömür \& } \\
\text { Bellikli } \\
(2019)\end{array}$ & $\begin{array}{l}\text { Samsun, } \\
\text { Trabzon, } \\
\text { Giresun- } \\
\text { Türkiye }\end{array}$ & $\begin{array}{l}\text { Mann Whitney U } \\
\text { testi, Kruskal Wallis } \\
\text { H testi ve Spearman } \\
\text { korelasyon analizi }\end{array}$ & $\begin{array}{l}\text { Ampirik çalşsmada vergi bilinci, vergi ahlakı ve vergileme konusunda kamu otoritesine } \\
\text { duyulan güven ile vergi tahakkuk-tahsilat oranları arasında anlamlı bir ilişki olduğu tespit } \\
\text { edilmiştir. }\end{array}$ \\
\hline $\begin{array}{l}\text { Uyanık } \\
(2019)\end{array}$ & Türkiye & Çapraz tablo analizi & $\begin{array}{l}\text { Elde edilen bulgulara göre vergiye gönüllü uyum üzerinde haksız vergi rekabetinin ve vergi } \\
\text { aflarının olumsuz etki doğurabileceği sonucuna ulaşılmıştır. Devlete ve siyasal iktidara } \\
\text { güven, sosyal ve ekonomik gelişmeler ile vergi adaleti gibi faktörlerin ise vergiye gönüllü } \\
\text { uyumu olumlu etkilediği tespit edilmiştir. }\end{array}$ \\
\hline $\begin{array}{c}\text { Djajanti } \\
(2020)\end{array}$ & $\begin{array}{c}\text { Cakarta- } \\
\text { Endonezya }\end{array}$ & $\begin{array}{l}\text { Kısmi en küçük } \\
\text { kareler yapısal eşitlik } \\
\text { modellemesi (PLS- } \\
\text { SEM) }\end{array}$ & $\begin{array}{l}\text { Çalışma neticesinde vergi otoritesinin gücü ve vergi otoritesine duyulan güven faktörlerinin } \\
\text { vergiye gönüllü uyum üzerinde pozitif etkisi olduğu ortaya çıkmıştır. Vergi sistemindeki } \\
\text { adalet ile vergiye gönüllü uyum arasında ise negatif bir ilişki olduğu bulunmuştur. Çalışmanın } \\
\text { sonuçları, kaygan yamaç modelinin gelişimini destekler niteliktedir. }\end{array}$ \\
\hline
\end{tabular}

Çalışmanın konusu ile ilgili literatür incelendiğinde, yapılan ampirik çalışmaların birçoğunda ele alınan değişkenlerin vergiye gönüllü uyum üzerinde etkileri konusunda bir uzlaşıya varılamamıştır. Örneğin, Serim'in (2015) çalışmasında arkadaş ve aile çevresinin içinde bulunduğu referans grup faktörünün vergiye gönüllü uyum üzerinde pozitif etkisi olduğu ortaya konulurken, Deyganto'nun (2018) çalışmasında referans grubun vergiye gönüllü uyum üzerinde etkisinin olmadığı tespit edilmiştir. Benzer şekilde Uyanık (2019) tarafından yapılan çalışmada vergi adaleti faktörünün vergiye gönüllü uyum üzerinde anlamlı bir etkisinin olduğu tespit edilirken, Deyganto'nun (2018) çalışmasında ise vergi adaletinin gönüllü uyum üzerinde önemli bir etkisinin olmadığı tespit edilmiştir.

\section{Araştırmanın Metodolojisi}

Çalışmanın amacı, vergi mükelleflerinin vergiye gönüllü uyumuna etki eden faktörlerin belirlenmesidir. Çalışmadaki temel amaçlar aşağıdaki gibi belirlenmiştir:

- Bireysel faktörlerin, örneğin mükellefin vergi bilgisi ve cezalar konusunda farkındalığının vergiye gönüllü uyum üzerindeki etkisini belirlemektir.

- Ekonomik faktörlerin, örneğin mükellefin gelir düzeyinin vergiye gönüllü uyum üzerindeki etkisini belirlemektir.

- Kurumsal faktörlerin, örneğin vergi idaresinin etkin ve adaletli çalışmasının vergiye gönüllü uyum üzerindeki etkisini belirlemektir. 
Tabakan, G. \& O. Avc1 (2021), "Vergiye Gönüllü Uyumu Etkileyen Faktörlerin Lojistik Regresyon Analizi ile Belirlenmesi”, Sosyoekonomi, 29(48), 541-561.

- Sosyal faktörlerin, örneğin tanıdık insanların vergi kaçırması, referans grubun vergiye gönüllü uyum üzerindeki etkisini belirlemektir.

Çalışmanın örneklemini Adana ilinde bulunan 743 vergi mükellefi oluşturmaktadır. Çalışmada, mükelleflerin vergiye gönüllü uyumunu değerlendirebilmek amacıyla literatürde yer alan çalışmalardan faydalanılarak anket formu oluşturulmuştur (Tuay \& Güvenç, 2007; Öz-Yalama \& Gümüş, 2013). Anket 5'li likert ölçeğe göre düzenlenmiş (Kesinlikle Katılmiyorum, Katılmıyorum, Kararsızım, Katılıyorum, Kesinlikle Katılıyorum) 2 bölümden oluşmaktadır. Birinci bölüm mükelleflerin; yaşı, cinsiyeti, medeni durumu, öğrenim durumu, yıllık gelir düzeyi vb. demografik değişkenlerden; ikinci bölüm ise, mükelleflerin vergiye gönüllü uyumunu etkileyen faktörleri belirlemeye yönelik ifadelerden oluşmaktadır.

Vergiye gönüllü uyum davranışı doğası gereği iki kategorili niteliksel veri tipinde olduğundan (gönüllü uyum sağlayan ve gönüllü uyum sağlamayan) çalışmada vergiye gönüllü uyumu etkileyen faktörlerin belirlenmesi amacı ile iki kategorili (binary) lojistik regresyon analizi tercih edilmiştir.

Regresyon analizi, değişkenler arasındaki ilişkinin matematiksel bir model ile açıklanmasıdır. Regresyon analizinde bir bağımlı değişkendeki değişim, iki ya da daha fazla bağımsız değişken tarafından açıklanıyorsa çoklu regresyon analizi kullanılmaktadır. Regresyon analizinde değişkenler arasındaki ilişkiler doğrusal ise "Doğrusal Regresyon Analizi”, değilse "Doğrusal Olmayan (Eğrisel) Regresyon Analizi” olarak isimlendirilmektedir (Büyüköztürk, 2018: 91). Doğrusal regresyon analizinde bağımsız değişkenler sürekli ve kesikli niceliksel (sayısal) değişkenler olabileceği gibi sırasız ve sıralı niteliksel veri tipinde olabilmektedir. Bağımlı değişken ise, sürekli nicel veri türündedir. Bununla birlikte uygulamada, bağımlı değişkenin kesikli niceliksel veri tipinde olduğu durumlarla da karşılaşılır. Diğger taraftan, bağımlı değişkenin iki ya da daha çok düzeyli niteliksel veri olması söz konusudur. Böyle durumlarda, bağımlı ve bağımsız değişken(ler) arasındaki ilişki lojistik regresyon yardımı ile incelenir (Alpar, 2011: 409).

Lojistik regresyon analizi, bağımlı değişkenin ikili veya çoklu kategorilerde gözlendiği durumlarda, bağımsız değişkenlerin bağımlı değişken ile sebep sonuç ilişkisini belirlemeye yarayan parametrik olmayan bir istatistiksel yöntemdir. Bağımsız değişkenlere göre, bağımlı değişkeninin beklenen değerini olasılık olarak hesaplayan ve olasılık kurallarına göre sınıflama ve atama işlemini yapmaya yardımcı olan bir regresyon yöntemidir (Özdamar, 2004: 589).

Doğrusal regresyonda bağımlı değişkenin sürekli olması, normal dağılım göstermesi ve hata terimlerinin varyansının normal dağılım göstermesi gerekirken, lojistik regresyonda bağımlı değişkenin niteliksel tipte verilerden oluşması ve dağılım için herhangi bir varsayım gerektirmemesi lojistik regresyonun esnek bir model olmasını sağlamaktadır. Lojistik regresyon modelinin bu esnekliği, sağlık alanından eğitim bilimlerine kadar birçok disiplinde kullanılmasını sağlamaktadır. Lojistik regresyonda bağımsız değişkenler 
niceliksel ya da niteliksel veri tipinde olabilmektedir. Bağımlı değişken iki kategorili niteliksel değişken ise "iki (binary) kategorili lojistik regresyon", ikiden çok sayıda kategorili ve sırasız ise "çok kategorili (multinominal) lojistik regresyon" ve ikiden çok sayıda kategorili ve siralanabilirse "sıralı (ordinal) lojistik regresyon" yöntemleri kullanılmalidır (Alpar, 2011: 615).

Lojistik regresyon modeli,

$$
\pi(X)=E\left(Y / X_{1}, X_{2}, \ldots, X_{k}\right)=\frac{e^{\beta_{0}+\beta_{1} X_{1}+\cdots++\beta_{k} X_{k}}}{1+e^{\beta_{0}+\beta_{1} X_{1}+\cdots++\beta_{k} X_{k}}}
$$

olup (1) denkleminde, $\pi(X)$ incelenen olayın gözlenme sıklığını, $\beta_{0}$ sabiti bağımsız değişkenler sıfır değerini aldığında bağımlı değişkenin değerini, $\beta_{1}, \beta_{2}, \ldots, \beta_{k}$ bağımsız değişkenlerin regresyon katsayılarını, $X_{1}, X_{2}, \ldots, X_{k}$ ( $k$ tane $)$ bağımsız değişkenleri göstermektedir. Eşitlik (1)'de olasılık değerleri üzerinde $\frac{\pi(X)}{1-\pi(X)}$ dönüşümü yapılıp, bu olasılık oranının doğal logaritması alınırsa bağımlı değişkenin sınırları $(-\infty, \infty)$ arasında olacaktır. Bu dönüşüm ile elde edilen yeni bağımlı değişkeni bağımsız değişkenlerin doğrusal bir fonksiyonu olarak (2) eşitliğindeki gibi yazabiliriz. $\pi(X)^{\prime} i(-\infty, \infty)$ aralığında tanımlı hale getiren bu dönüşüme "lojit dönüşüm" denir ve bu dönüşüm $\pi(X)$ cinsinden,

$$
g(X)=\ln \left(\frac{\pi(X)}{1-\pi(X)}\right)=\beta_{0}+\beta_{1} X_{1}+\cdots++\beta_{k} X_{k}
$$

olarak yazılır. Lojit olarak adlandırılan $g(x)$ fonksiyonu parametreleri bakımından doğrusal olup, bağımsız değişkenin aldığı değerlere göre $(-\infty, \infty)$ aralığında değişebilen bir fonksiyondur (İyit \& Genç, 2005: 20; Yorubulut \& Erdugan, 2018: 187; Kubar \& Kıral, 2019: 361).

Lojistik regresyonda olasılık (odds) oranı, incelenen iki olayın gözlemlenme olasılıklarından birinin diğerine (referans kategoriye) oranla kaç kat daha fazla veya kaç kat daha az olarak ortaya çıkabileceğini gösterir. Lojistik regresyon modelinin lojiti olan $\mathrm{g}(\mathrm{X})$ fonksiyonunun anti logaritması alındığında olasılık oranına ulaşılır:

$$
\text { Olasılık Oranı }=\frac{\pi(X)}{1-\pi(X)}=e^{\beta_{0}+\beta_{1} X_{1}+\cdots++\beta_{k} X_{k}}
$$

Lojistik regresyon modelinde tahmin edilen regresyon katsayılarının yorumlanması doğrusal regresyon modelinden farklıdır. Lojistik regresyonda, regresyon katsayıları $\beta_{1}, \beta_{2}, \ldots, \beta_{k}$ olasılık oranına ilişkin değişim ölçüleridir. Lojistik regresyon analizinde katsayıları yorumlama için ya orijinal ya da üstel lojistik katsayılar kullanılabilmektedir. Orijinal katsayılar, logit değerindeki değişimi yansıttığı için ilişkinin büyüklüğü belirlenirken daha az kullanışlıdır ancak ilişkinin yönünü (pozitif veya negatif) belirlemede doğrudan kullanılabilmektedirler. Pozitif katsayı bağımlı değişkendeki olasılı̆̆1 yükseltirken, negatif katsayı düşürmektedir. İlişkinin büyüklüğü belirlenirken üstel katsayıların $(\operatorname{Exp}(\beta))$ kullanımı bağımlı değişkendeki değişimin yüzde olarak ifade edilmesini [(Üstel katsayı-1)*100] sağladığı için orijinal katsayılara göre daha kullanışlıdır 
(Çokluk, 2010: 1390-1391). 1,00'in üzerinde üstel katsay1 pozitif ilişkiyi, 1,00'den küçük katsayı ise, negatif ilişkiyi gösterir.

Lojistik regresyonda modelin uyum iyiliğini ve performansını belirlemede; klasik regresyon modellerinde kullanılan $R^{2}$ istatistikleri yerine çeşitli açıklayıcılık katsayıları (yapay $R^{2}$ değerleri) kullanılmaktadır. Bunlar arasında en sık kullanılanları, Cox ve Snell $R^{2}$, Nagelkerke $R^{2}$ ve McFadden $R^{2}$ istatistikleridir. $\mathrm{Bu}$ istatistikler doğrusal regresyondakinden farklı şekilde yorumlanır. $\mathrm{Bu}$ yapay $R^{2}$ değerlerinin 0,20 ile 0,40 arasında olması yeterli kabul edilmektedir (Alpar, 2011: 643-645).

Çalışmada anket yoluyla elde edilen veriler SPSS (Statistical Package for Social Sciences) for Windows 20.0 istatistik paket programı kullanılarak analiz edilmiştir. Çalışmada öncelikle kullanılan anketin güvenirliliğinin değerlendirilmesi ve ankette yer alan soruların homojen yapı gösteren bir bütünü ifade edip etmediğinin araştırılması amacı ile güvenilirlik analizi yapılmış ve Cronbach $\alpha$ değeri hesaplanmıştır. Verileri değerlendirmede parametrik ya da parametrik olmayan testlerin kullanımına karar verebilmek için Kolmogorov-Smirnov normallik testi uygulanmıştır ve anlamlılık düzeyi $p<0,05$ olarak kabul edilmiştir. Bağımsız değişkenler arasında çoklu iç ilişkinin varlığını tespit etmek amacı ile korelasyon analizi yapılmış, tolerans, varyans şişirme faktörü (VIF) değerleri incelenmiştir. Çalışmanın bağımlı değişkeni olan vergiye gönüllü uyumu etkileyen faktörlerin belirlenmesi için ki-kare bağımsızlık testi uygulanmış ve test sonucunda belirlenen olası risk faktörleri iki kategorili lojistik regresyon analizine dahil edilmiştir.

\section{Araştırmanın Ampirik Bulguları}

Cronbach $\alpha$ güvenilirlik katsayısının $0,80 \leq \alpha \leq 1,00$ arasında olması durumunda anket sorularının yüksek derecede güvenilir olduğu söylenebilir. Çalışmada demografik değişkenler güvenilirlik analizine dahil edilmemiş olup, kullanılan ankete ait güvenilirlik katsayısı (Cronbach $\alpha$ ) 0,820 olarak elde edilmiştir. Bu nedenle kullanılan anketin yüksek derecede güvenilir olduğunu ve sorulara verilen cevapların \%82 oranında anlamlı olduğunu söyleyebiliriz. Kolmogorov-Smirnov testi sonucunda verilerin dağılımın normal olmadığ görülmüştür $(p<0,05)$. Bundan dolayı, gerçekleştirilecek analizlerde parametrik olmayan testler olan ki-kare bağımsızlık testi ile iki kategorili Lojistik Regresyon analizinin kullanılmasına karar verilmiştir. Verilerin homojenlikleri incelendiğinde ise, homojen yapıda olmadıkları tespit edilmiştir.

Çalışmaya katılan mükelleflerin demografik bilgilerine ilişkin değişkenler; yaş, cinsiyet, medeni durum, öğrenim durumu, yıllık gelir ve mükellefiyet türüdür. Katılımcıların \%60,3'ü erkek mükelleflerden oluşurken, \%39,7'si kadın mükelleflerden oluşmaktadır. Katılımcıların \%50,6'sı evli, \%39,8'i bekâr, \%5,4'ü nişanlı, \%4,2'si ise boşanmış/dul/eşinden ayrı yaşamaktadır. Mükelleflerin \%54,0'ü lisans ve lisansüstü, \%11,4'ü ön lisans, \%23,0'ü lise, \%11,1'i ilkokul ve ortaokul mezunu iken, \%0,5'i ise hiçbir diplomaya sahip değildir. Genel itibariyle katılımcıların ortalamanın üzerinde bir eğitim düzeyine sahip oldukları söylenebilir. Mükelleflerin \%22,6’sı 18-24 yaş aralığında, \%33,4’ü 
25-34 yaş aralığında, \%26,6'sı 35-49 yaş aralığında, \%14,4’ü 50-59 yaş aralığında iken $\% 3,1$ 'i 60 ve üzeri yaş aralığındadır. Ankete katılan vergi mükelleflerinin aylık bireysel ortalama gelir düzeylerine bakıldığında, hiç geliri olmayan mükelleflerin \%4,4 oranında, gelir düzeyi 500 TL'den az olan mükelleflerin \%3,4 oranında, 500-1499 TL arasında gelire sahip olanların \%15,3 oranında, 1500-1894 TL arasında gelire sahip olanların \%5,2 oranında, 1895-4000 TL arasında gelire sahip olanların \%42,6 oranında, 4001-6250 arasında gelire sahip olanların \%20,5 oranında, 6251-15000 TL arasında gelire sahip olanların \% 7,4 oranında ve aylık bireysel ortalama geliri 15000 TL ile üzerinde olanların \%1,2 oranında olduğu görülmüştür. Katılımcıların, yaklaşık \%53,8'lik kısmı gelir vergisi mükellefi, \%6,6'sı kurumlar vergisi mükellefi, \%26,6's1 KDV/ÖTV/MTV ve \%13,0'ü diğer vergi mükelleflerinden oluşmaktadır.

Çalışmada "Vergiye Gönüllü Uyum Sağlama Davranışı" (UYUM: GÖNÜLLÜ UYUM) bağımlı değişkendir. Bağımsız değişkenler; "Tanıdık birinin etkisi”" (RGRUP: REFERANS GRUP), "Vergi aflarının uygulanması" (VAF: VERGİ AFFI), "Vergi kaçakçılığ1 suçu için öngörülen cezaların farkındalığı” (VCEZA: VERGİ CEZALARI), "Vergi oranları hakkında farkındalık" (VORAN: VERGİ ORANLARI), "Vergi idaresinin etkin ve adaletli çalıştığının algılanması" (ETKINLIKK: VERGİ İDARESINIIN ETKİNLİĞİ ve ADALETI), "Vergi kaçırmanın yanlış bir davranış olduğu ve sonucunda suçluluk duygusunun hissedilmesi" (VİCDAN: VİCDAN AZABI), "Denetlenme olasılığı (yetersiz denetim)" (DENETIM), "Mükellefin gelir düzeyi" (GELIR), "Dinsel faktörler" (DİN: DİNI DUYARLILIK), "Mükellefin vergiler hakkındaki bilgi düzeyi" (VBİLGİ: VERGİ BİLGISİ) olarak belirlenmiştir.

Çalışmada bağımlı değişken ile bağımsız değişkenler arasındaki ilişkinin belirlenmesi amacıyla yapılan ki-kare testi sonuçları Tablo 2'de gösterilmiştir. Bu sonuçlara göre, bağımlı değişken ile tüm bağımsız değişkenler arasındaki farklar istatistiksel olarak anlamlı bulunmuştur $(p<0,05)$. Tüm bağımsız değişkenlerin, bağımlı değişken üzerinde anlamlı bir etkiye sahip olduğu söylenebilir. Bu durumda anlamlı bulunan tüm bağımsız değişkenlerin olası risk faktörleri olarak lojistik regresyon analizine alınması uygundur.

Tablo: 2

\section{Bağımsız Değişkenler ile Gönüllü Uyum Değişkeninin Ki-Kare Testi Sonuçları}

\begin{tabular}{|l|c|c|}
\hline \multicolumn{1}{|c|}{ Iffadeler } & Pearson Ki-Kare & p \\
\hline REFERANS GRUP (RGRUP) & 82,200 & $\mathbf{0 , 0 0 0}$ \\
\hline VERGİ AFFI (VAF) & 260,789 & $\mathbf{0 , 0 0 0}$ \\
\hline VERGİ CEZALARI (VCEZA) & 236,386 & $\mathbf{0 , 0 0 0}$ \\
\hline VERGI ORANLARI (VORAN) & 295,858 & $\mathbf{0 , 0 0 0}$ \\
\hline VERGİ İDARESININ ETKİNLIĞİ ve ADALETİ (ETKINNLIK) & 279,758 & $\mathbf{0 , 0 0 0}$ \\
\hline VİCDAN AZABI (VİCDAN) & 276,988 & $\mathbf{0 , 0 0 0}$ \\
\hline DENETIM & 256,574 & $\mathbf{0 , 0 0 0}$ \\
\hline GELİ & 219,011 & $\mathbf{0 , 0 0 0}$ \\
\hline DINİ DUYARLILIK (DIN) & 259,531 & $\mathbf{0 , 0 0 0}$ \\
\hline VERGİ BİGİंİ (VBİLII) & 281,409 & $\mathbf{0 , 0 0 0}$ \\
\hline
\end{tabular}

Çalışmada bağımlı değişken vergiye gönüllü uyum üzerinde etkili olan riskli faktörlerin belirlenmesi amacı ile iki kategorili lojistik regresyon analizinin uygulanması için bağımlı değişkenin iki kategoriye dönüştürülmesi gerekmektedir. Literatürde 
Tabakan, G. \& O. Avc1 (2021), "Vergiye Gönüllü Uyumu Etkileyen Faktörlerin Lojistik Regresyon Analizi ile Belirlenmesi”, Sosyoekonomi, 29(48), 541-561.

“Kararsızım” ifadesinin olumsuz görüş bildiren kategorilerle (Kesinlikle Katılmıyorum ve Katılmıyorum) birleştirildiği çalışmaların olduğu görülmektedir (Goldacre vd., 2010: 2). Bu nedenle çalışmada bağımlı değişken olan 'GÖNÜLLÜ UYUM' değişkeninin olumsuz görüş bildiren Kesinlikle Katılmıyorum, Katılmıyorum, Kararsızım kategorileri "Katılmıyorum" ve olumlu görüş bildiren Katılıyorum, Kesinlikle Katılıyorum kategorileri "Katılıyorum" şekline dönüştürülmüştür. Mükelleflerin vergiye uyumu konusunda iki durum söz konusudur: Mükellefler vergiye gönüllü uyum (olumlu uyumluluk davranışı) veya gönüllü olmadan (olumsuz uyumluluk davranışı) uyum gösterebilirler. Eğer mükellefler vergilerini vergi dairelerine zamanında, doğru olarak, herhangi bir yasal zorunluluk olmadan yetkililerin talimatlarına ve düzenlemelerine uyarak ödüyorlarsa vergiye gönüllü uyum söz konusudur. Bunun aksine mükellefler vergi otoritelerinin denetim, para cezasi vb. uygulamaları nedeniyle vergilerini ödeme yoluna gidiyorlarsa olumsuz uyumluluk davranışı söz konusudur. Bu teorik çerçeveden hareketle, vergiye gönüllü uyum bağımlı değişkeni iki kategorili niteliksel bir değişken olduğundan çalışmada gönüllü uyumluluk tutumu için bir (1), aksi durum için sıfır (0) kodlaması yapılmıştır.

Lojistik regresyon analizinde; bağımsız değişkenler arasında çoklu iç ilişki probleminin olmaması gerekmektedir. Çoklu iç ilişki problemi genelde değişkenler arasında yüksek korelasyon olması nedeni ile ortaya çıkmaktadır. Genelde bağımsız değişkenler arasındaki düşük düzeydeki çoklu iç ilişki sorun yaratmazken, yüksek düzeydeki çoklu iç ilişki, örneğin iki değişken arasında $r=0,8$ 'lik bir ilişki olması gerçekte etkisi önemli olan bir değişkenin modele katkısının istatistiksel olarak önemsiz bulunmasına neden olabilir. Çalışmada yapılan korelasyon analizi sonucunda vergi affı (VAF), vergi oranları (VORAN), denetim (DENETIM) ve gelir (GELİR) değişkenleri ile vergiye gönüllü uyum (GÖNÜLLÜ UYUM) değişkeni arasında istatistiksel olarak anlamlı ve negatif yönde bir ilişki varken, vergi cezaları (VCEZA), vergi idaresinin etkinliği ve adaleti (ETKİNLİK), vicdan azabı (VİCDAN), dini duyarlılık (DIN) ve vergi bilgisi (VBİLGİ) değişkenleri ile vergiye gönüllü uyum (UYUM) değişkeni arasında istatistiksel olarak anlamlı pozitif yönde bir ilişki vardır. Elde edilen sonuçlara göre en yüksek pozitif korelasyon katsayısı etkinlik ve vergi affı arasında 0,466 iken en yüksek negatif korelasyon katsayısı denetim ile vergi affı arasında 0,509 olarak bulunmuştur. Gönüllü uyum değişkeni ile en yüksek korelasyona sahip olan değişken vergi affı olup, aralarında negatif yönde anlamlı bir ilişki vardır ( $\mathrm{p}=0,000)$. Çalışmada, bağımsız değişkenler arasında korelasyon değerlerinin $r<0,5$ olduğu tespit edilmiştir. Lojistik regresyonda bağımsız değişkenler arasındaki çoklu iç ilişkinin varlığını ortaya koymak için doğrusal regresyonda kullanılan tolerans ve varyans şişirme faktörü (VIF) değerleri de incelenebilir. Bağımsız değişkenlere ait 10'un altında olan VIF değerleri ve 0,1 'in üstünde olan tolerans değerleri çoklu iç ilişki probleminin olmadığını göstermektedir (Alpar, 2011: 638). Bağımsız değişkenlere ait tolerans ve VIF değerleri Tablo 3'te yer almaktadır. Tablodan bağımsız değişkenler için tolerans ve VIF değerlerinin kritik değerler aralığında olduğu görülmektedir. Sonuç olarak bağımsız değişkenler arasında çoklu iç ilişki probleminin olmadığg söylenebilir. 
Tablo: 3

Çoklu İç İlişki Sonuçları

\begin{tabular}{|l|c|c|}
\hline Değisken & Tolerans & VIF \\
\hline REFERANS GRUP(RGRUP) & 0,942 & 1,062 \\
\hline VERGİ AFFI (VAF) & 0,533 & 1,875 \\
\hline VERGİ CEZALARI (VCEZA) & 0,603 & 1,659 \\
\hline VERGİ ORANLARI (VORAN) & 0,560 & 1,785 \\
\hline VERGİ İDARESININ ETKINLIĞİ ve ADALETİ (ETKINLIK) & 0,506 & 1,978 \\
\hline VICDAN AZABI (VICDAN) & 0,646 & 1,548 \\
\hline DENETIM & 0,536 & 1,865 \\
\hline GELİ & 0,795 & 1,258 \\
\hline DINİ DUYARLILIK (DİN) & 0,837 & 1,195 \\
\hline VERGİ BİGİİ (VBİGI) & 0,767 & 1,305 \\
\hline
\end{tabular}

Çalışmada lojistik regresyon modelindeki katsayıların anlamlılığını değerlendirmek için Omnibüs testi uygulanmıştır. Bağımsız değişkenlerin yer aldığ 1 model ile sadece sabit değişkenin yer aldığı model arasında anlamlı bir farklılığın olduğu görülmüştür $\left(\chi^{2}=\right.$ $220,245 ; p=0,000)$. Diğer bir ifade ile modele eklenen bağımsız değişkenlerden en az birinin bağımlı değişkenin tahmininde katkısı bulunmaktadır.

Lojistik regresyon modelinin uyum iyiliğinin değerlendirilmesinde kullanılan Hosmer-Lemeshow testi, elde edilen modelin veriye uyumunun iyi olup olmadiğını tespit etmede kulanılan yöntemlerden biridir. Bu test, model tarafından kestirilen değerler ile gözlenen değerler arasında anlamlı bir farkın olup olmadığını test etmektedir. Bu teste ilişkin sonucun anlamlı olmaması ( $p>0,05)$, model-veri uyumunun yeterli düzeyde olduğunu diğer bir ifade ile modelin kabul edilebilir uyuma sahip olduğunu gösterir (Toraman \& Karaca, 2016). Yapılan test sonucunda kestirim değerleri ile gözlem değerleri arasında anlamlı bir farklılığın olmadığı başka bir deyişle uyum iyiliğinin sağlandığ 1 sonucuna varılmıştır $\left(\chi^{2}=\right.$ $7,779 ; p=0,455>0,05)$.

Çalışmada lojistik regresyon açıklayıcılık katsayılarının ( $\mathrm{R}^{2}$ istatistikleri) değerleri bağımlı değişkenin yüzde kaçının bağımsız değişkenler tarafından açıklandığını göstermektedir. Buna göre, modelde yer alan bağımlı değişkenin bağımsız değişkenlerle açıklanma düzeyi Cox-Snell'e göre \%25,7 ve Nagelkerke'ye göre ise, \%36,3 olarak belirlenmiştir.

\section{Tablo: 4}

Model Sinıflandirma Tablosu ${ }^{\mathrm{a}}$

\begin{tabular}{|c|c|c|c|c|}
\hline \multirow{2}{*}{ Gözlenen } & \multicolumn{2}{c|}{ Tahmin Edilen } \\
\cline { 3 - 5 } & & \multicolumn{2}{c|}{ Vergiye Gönüllü Uyum } & Doğruluk Yüzdesi \\
\cline { 3 - 5 } & Evet & 118 & 106 & 52,7 \\
\hline \multirow{2}{*}{ Vergiye Gönüllü Uyum } & Hayır & 41 & 478 & 92,1 \\
\hline Genel Yüzde & & & & 80,2 \\
\hline
\end{tabular}

a. Kesim değeri 0,5 'tir.

Lojistik regresyon sonucunda elde edilen model sinıflandırma tablosu (Tablo 4) kategorize edilen bağımlı değişkene atamaları göstermektedir. Analize devam edilebilmesi için hesaplanan doğru atama oranının \%50'den büyük olması gerekmektedir (Kubar \& Kıral, 
2019: 363). Model sınıflandırma tablosundan doğru atama oranının \%80,2 olduğu görülmekte olup bu oran analize devam için yeterli bir göstergedir.

Çalışmada yapılan tüm analizler sonucunda modelin açıklayıcılığının ve uyumunun iyi düzeyde olduğu söylenebilir. Buradan hareketle yapılan ki-kare bağımsızlık testi sonucunda (Tablo 2) bağımlı değişken üzerinde etkisi önemli bulunan tüm bağımsız değişkenler iki kategorili lojistik regresyon analizine tâbi tutulmuştur.

Tablo: 5

İki Kategorili Lojistik Regresyon Sonuçları

\begin{tabular}{|c|c|c|c|c|c|c|c|c|}
\hline \multirow{2}{*}{ Değișkenler } & \multirow{2}{*}{$\beta$} & \multirow{2}{*}{$S E(\beta)$} & \multirow{2}{*}{ Wald } & \multirow{2}{*}{ s.d } & \multirow{2}{*}{$P$} & \multirow{2}{*}{$\operatorname{Exp}(\beta)$} & \multicolumn{2}{|c|}{ 95\% C.I.for $\operatorname{Exp}(\beta)$} \\
\hline & & & & & & & Alt & Üst \\
\hline REFERANS GRUP (RGRUP) & $\mathbf{0 , 7 2 0}$ & 0,226 & 10,115 & 1 & 0,001 & 2,055 & 1,318 & 3,203 \\
\hline VERGİ AFFI (VAF) & $-1,392$ & 0,217 & 41,053 & 1 & 0,000 & 0,249 & 0,162 & 0,381 \\
\hline VERGİ CEZALARI (VCEZA) & $-0,123$ & 0,240 & 0,262 & 1 & 0,609 & 0,885 & 0,553 & 1,415 \\
\hline VERGİ ORANLARI (VORAN) & $-0,515$ & $\mathbf{0 , 2 3 5}$ & 4,801 & 1 & $\mathbf{0 , 0 2 8}$ & 0,598 & $\mathbf{0 , 3 7 7}$ & 0,947 \\
\hline VERGİ İDARESİNIN ETKİNLİĞİ ve ADALETİ (ETKİNLIK) & 0,305 & 0,241 & 1,594 & 1 & 0,207 & 1,356 & 0,845 & 2,177 \\
\hline VICDAN AZABI (VICDAN) & $\mathbf{0 , 7 5 3}$ & $\mathbf{0 , 2 1 2}$ & 12,649 & 1 & $\mathbf{0 , 0 0 0}$ & 2,123 & 1,402 & 3,215 \\
\hline DENETİM & $-0,659$ & 0,244 & 7,264 & 1 & $\mathbf{0 , 0 0 7}$ & 0,518 & $\mathbf{0 , 3 2 1}$ & 0,836 \\
\hline GELİR & 0,394 & 0,222 & 3,142 & 1 & 0,076 & 1,483 & 0,959 & 2,294 \\
\hline DİNİ DUYARLILIK (DİN) & 0,746 & 0,217 & 11,820 & 1 & 0,001 & 2,108 & 1,378 & 3,225 \\
\hline VERGİ BİLGİSİ (VBİLGİ) & 0,482 & 0,205 & 5,515 & 1 & $\mathbf{0 , 0 1 9}$ & 1,619 & $\mathbf{1 , 0 8 3}$ & 2,421 \\
\hline SABİT TERİM & 0,068 & 0,343 & 0,039 & 1 & & 1,070 & & \\
\hline
\end{tabular}

Bağımlı değişkene etki eden değişkenlere ait lojistik regresyon analizi sonuçları Tablo 5'te gösterilmiştir. Tabloda, modelde yer alan bağımsız değişkenlere ait katsayı tahminleri ve bu tahminlerin standart hataları $(S E(\beta))$, Wald istatistiği, Wald istatistiği serbestlik derecesi $(s . d)$, olasılık oranı $(\operatorname{Exp}(\beta))$ ve \%95 güven aralığında olasılık oranlarının aralık tahminleri görülmektedir. Wald test istatistiği, her bir bağımsız değişken için lojistik regresyon katsayısının anlamlılığını test etmede yaygın olarak kullanılan bir testtir. Bir başka deyişle bu test, herhangi bir logit katsayısının sıfıra eşit olduğu şeklindeki null hipotezini test eder. Wald test istatistiği, $W=\left(\frac{\widehat{\beta} j}{S E(\widehat{\beta} j)}\right)^{2} i=1, \ldots, k$ biçiminde ifade edilir ve lojistik regresyonda $\beta$ katsayısının anlamlılık testine karşılık gelir (Çokluk, 2010: 1375). Tabloda yer alan $\operatorname{Exp}(\beta)$ üstel lojistik regresyon katsayılarıdır.

Tablo 5'e göre 'REFERANS GRUP', 'VERGİ AFFI', 'VERGİ ORANLARI', 'VİCDAN AZABI, 'DENETIM', 'DINI DUYARLILIK' ve 'VERGİ BİLGİSI' değişkenlerinin bağımlı değişken olan GÖNÜLLÜ UYUM üzerinde anlamlı bir etkiye sahip olduğu $(p<0,05)$, 'VERGİ CEZALARI', 'VERGİ İDARESININ ETKİNLİĞİ ve ADALETI' ile 'GELİR' değişkenlerinin modele anlamlı bir katkısının olmadı̆̆ görülmektedir $(p>0,05)$. Buna göre lojistik regresyon modeli şu şekildedir:

$$
\begin{aligned}
& g(X)=0,068+0,720(\text { RGRUP })-1,392(\text { VAF })-0,515(\text { VORAN })+0,753(V \dot{I} C D A N)- \\
& 0,659(\text { DENETIM })+0,746(D \dot{I} N)+0,482(V B \dot{\mathrm{I}} L G \dot{\mathrm{I}})
\end{aligned}
$$

Tablo 5'te $\operatorname{Exp}(\beta)$ sütunu her bir değişken için hesaplanan olasılık oranlarını göstermektedir. Olasılık oranlarını yorumlamak $\beta$ katsayılarını yorumlamaktan daha kolaydır. $\operatorname{Exp}(\beta)$ değerleri şu şekilde yorumlanır: Eğer olasılık oranı 1'den büyükse bir 
sonucun meydana gelme olasılığ́ artış yönünde, 1 'den küçük ise sonucun meydana gelme olasılığı azalış yönünde yorumlanır. Buna göre Tablo 5 'te anlamlı bulunan değişkenler için aşağıdaki yorumlar yapılabilir.

Tablo 5 incelendiğinde, REFERANS GRUP faktörünün bağımlı değişken gönüllü uyum üzerinde pozitif yönde anlamlı bir etkiye sahip olduğu görülmektedir ( $\beta=$ $0,720 ; p<0,05)$. Nitekim Allingham \& Sandmo (1972) çalışmalarında aile ve arkadaş grubunun vergiye gönüllü uyumu önemli derecede etkilediğini ortaya koymuşlardır. Ayrıca, Adimassu \& Jerene'nin (2016) çalışmasında da referans grubun vergiye gönüllü uyum üzerinde pozitif etkisi olduğu ortaya konulmuştur. Ancak Deyganto'nun (2018) çalışmasında referans grubun etkisinin olmadığ 1 sonucuna varılmıştır. Elde edilen sonuçlara göre referans grup değişkeninde meydana gelecek 1 birimlik olumlu algı artışı vergiye gönüllü uyum olasılığında (olasılık oranında) \%105,5'lik [(2,055-1)*100] artışa yol açmaktadır. Artışa yol açtığına ilişkin belirleme, bu değişkene ilişkin olasılık oranının 1'den büyük olmasından kaynaklanmaktadır. Diğer bir ifade ile mükelleflerin tanıdıkları arasında, mensup olduğu gruplarda vergisini düzenli ödeyenler olduğu takdirde, kendisinde de vergisini doğru ödeme davranışı görülmektedir. Dolayısıyla kişinin yakın arkadaşları, iş arkadaşları, içinde bulunduğu grup vb., referans grupta bulunan kişilerin vergiye gönüllü uyum konusundaki tutumları ile kişinin vergiye gönüllü uyum konusundaki tutumu benzerlik gösterebilecektir. Referans gruptaki kişilerin gönüllü olarak vergisel sorumluluklarını yerine getirmeleri, kişinin kendisinin de vergiye gönüllü uyumunu arttırabilecektir. Mükelleflerin davranışlarını, vergi idaresi ile olan ilişkileri ve içinde bulundukları sosyal ortam oldukça etkilemektedir. Çünkü insanlar davranışlarını, iş arkadaşları ve aile bireyleri gibi belirli bir referans grubuna göre ayarlayabilmektedir (Çiçek vd., 2019: 230).

Tablo 5'e göre, VERGİ AFFI faktörü bağımlı değişken vergiye gönüllü uyum sağlama davranışı üzerinde negatif yönde anlamlı bir etkiye sahiptir $(\beta=-1,392 ; p<$ $0,05)$. Sik sik uygulanan vergi aflarının mükellefin vergiye gönüllü uyumu üzerinde olumsuz etkisi vardır. Vergi affı değişkenindeki 1 birimlik algı artışı, vergiye gönüllü uyum olasılığında \%75,1'lik [(1-0,249)*100] azalışa yol açmaktadır. Azalışa yol açtığına ilişkin belirleme, bu değişkene ilişkin olasılık oranının 1'den küçük olmasından kaynaklanmaktadır. Literatürde, vergi aflarının süreklilik arz edecek biçimde çıkarılmasının uzun vadede mükelleflerin gönüllü uyumunu negatif etkilediğine dair sonuçlar bulunmaktadır (Luitel \& Sobel, 2007; Çetin-Gerger, 2012). Tekin \& Sökmen-Gürçam (2017) çalışmalarında, sık sık tekrarlanan vergi aflarının mükelleflerin vergiye gönüllü uyumunu zedelediği sonucuna varmışlardır. Vergi aflarının dürüst mükelleflerin vergi uyumunu azalttığı ifade edilmiştir. $\mathrm{Bu}$ sonuçlar çalışmamızın sonucunu destekler niteliktedir. Ancak, literatürde vergi uyumu ile vergi afları arasında pozitif ilişki olduğunu ortaya koyan çalışmalar da bulunmaktadır (Okoye, 2019: 121; Mikesell \& Ross, 2012; Ashman vd., 2011). İsviçre ve Kosta Rika'da 122 kişinin katılımı ile gerçekleştirilen çalışmada vergi affının, vergiye gönüllü uyuma etkisini görmek amaçlanmıştır. Çalışmada, vergi affi ile gönüllü uyum arasında pozitif ilişki olduğu tespit edilmiştir (Torgler \& 
Schaltegger, 2005: 411). Nitekim Lerman (1986) çalışmasında her ne sebeple olursa olsun vergi aflarının vergi uyumunu olumlu ya da olumsuz yönde etkilediğini belirtmiştir.

Bağımlı değişken üzerinde anlamlı etkiye sahip olan diğer bir faktör VERGİ ORANLARI'dır. Vergi oranları, vergiye gönüllü uyum üzerinde üzerinde negatif yönde anlamlı bir etkiye sahiptir $(\beta=-0,515 ; p<0,05)$. Mükelleflerin vergi oranları ile ilgili algılarındaki 1 birimlik artış, vergiye gönüllü uyum olasılığında \%40,2'lik [(1-0,598)*100] azalışa yol açmaktadır. Başka bir deyişle, vergi oranlarının artması mükelleflerin vergiye gönüllü uyum olasılıklarını azaltmaktadır. Literatüre baktığımızda vergi oranlarının vergiye gönüllü uyum üzerinde negatif etki ettiğine dair çalışmalara; Clotfelter (1983), Graetz \& Wilde (1985), Feldstein (1995), Fisman \& Wei (2004) ve Mas'ud vd. (2014) örnek olarak gösterilebilir. Çalışmalar incelendiğinde genel olarak vergi oranları arttıkça gönüllü vergi uyumunun azaldı̆̆ görülmektedir.

Bağımlı değişken üzerinde pozitif yönde, istatistiksel olarak anlamlı bir etkiye sahip olan diğer bir faktör de VICDAN AZABI'dır $(\beta=0,753 ; p<0,05)$. Vicdan azabı değişkenindeki 1 birimlik artış, vergiye gönüllü uyum olasılığında \%112,3'lük [(2,1231)*100] artışa yol açmaktadır. Literatürdeki birçok önemli çalışma vicdan azabının (suçluluk duygusunun) vergi uyumu üzerinde pozitif etkisi olduğunu ortaya koymuştur. Pozitif yönde ilişki olduğuna dair; Scott \& Grasmick (1981) ve Grasmick \& Scott'un (1982) çalışmalarında rastlanılmaktadır. Elde edilen sonuç, söz konusu çalışmalardaki bulguları destekler niteliktedir.

Çalışmadan elde edilen sonuca göre, DENETİM faktörü ile vergiye gönüllü uyum arasında negatif yönde ve istatistiksel olarak anlamlı bir ilişki tespit edilmiştir $(\beta=-0,659 ; p<0,05)$. Denetim değişkenindeki 1 birimlik artış, vergiye gönüllü uyum olasılığında \%48,2'lik [(1-0,518)*100] azalışa yol açmaktadır. Vergi denetimi arttıkça mükellefler vergisel sorumluluklarını daha az yerine getirmekte ve bunun sonucu olarak vergiye gönüllü uyum sağlama davranışları azalmaktadır. Dolayısıyla örneklem grubunun denetim faktöründen olumsuz etkilendiğini söyleyemek mümkündür. Literatürde yer alan çalışmalar incelendiğinde vergilerin denetlenme olasılığı ile vergiye gönüllü uyum arasında farklı ilişkiler bulunmuştur. Jackson \& Jaouen (1989), Dubin (2007) ve Eisenhauer (2008) çalışmalarında, denetimin vergi kaçakçılığı üzerinde pozitif bir etkisi olduğu sonucuna varırken, bu çalışmaların tersine Adimassu \& Jerene (2016), denetimin vergi kaçakçılığı üzerinde negatif bir etkisi olduğu sonucuna varmışlardır. Beron vd., (1988) ise, denetimin vergi kaçırma ile anlamlı bir ilişki göstermediğini bildirmişlerdir.

Vergiye gönüllü uyum üzerinde pozitif yönde anlamlı bir etkiye sahip olan diğer bir faktör de DINII DUYARLILIK'tır $(\beta=0,746 ; p<0,05)$. Dini duyarlılık düzeyinde meydana gelecek 1 birimlik artış, vergiye gönüllü uyum olasılığında \%110,8'lik [(2,108$1)^{*} 100$ ] artışa yol açmaktadır. Dini inanç ile vergiye gönüllü uyum arasında pozitif ilişki olduğuna dair bulgular, Rajagukguk \& Sulistianti (2012), Palil vd. (2013), Mohdali \& Pope (2014), Güngör-Göksu \& İzgi-Şahpaz (2015), Benk vd. (2016), Kirchmaier vd.'nin (2018) çalışmalarında da tespit edilmiştir. Çalışmadan elde edilen bulgular mükelleflerin dini 
inancının arttıkça vergiye gönüllü uyum sağladığını destekler niteliktedir. Ancak Eiya vd.'nin (2016) çalışmasında dini faktörlerin tek başına vergiye gönüllü uyumu sağlamada yetersiz kaldığı sonucuna varılmıştır.

Son olarak, Tablo 5'ten VERGİ BİLGİSİ faktörünün bağımlı değişken vergiye gönüllü uyum sağlama davranışı üzerinde pozitif yönde anlamlı bir etkiye sahip olduğu görülmektedir $(\beta=0,482 ; p<0,05)$. Vergi bilgisi değişkenindeki 1 birimlik artışın, vergiye gönüllü uyum olasılığında \%61,9'luk [(1,619-1)*100] artışa yol açacağını söyleyebiliriz. Saad (2014), Damajanti \& Karim (2017), Newman \& Nokhu'nun (2018) çalışmaları da elde edilen sonucu destekler niteliktedir. Vergi bilgisinin vergiye gönüllü uyumu etkilemediğine dair sonuç ise, Fauziati vd.'nin (2016) çalışmasında tespit edilmiştir.

\section{Sonuç}

Bu çalışmada, lojistik regresyon analizi ile mükelleflerin vergiye gönüllü uyum sağlaması üzerinde etkili olan faktörlerin belirlenmesi amaçlanmıştır. Açıklanmaya çalışılan değişken vergiye gönüllü uyum davranışı, iki kategorili bir değişken olarak modelde tanımlanmıştır. Çalışmanın sonucu olarak, referans grupları, vergi affı, vergi oranları, vicdan azab1, vergi denetimi, dini duyarlılık ve vergi bilgisi faktörlerinin mükelleflerin vergiye gönüllü uyumunu etkilemede önemli bir rol oynadığı, vergi uyumunu istatistiksel olarak anlamlı bir şekilde etkilediği ancak vergi cezaları, vergi idaresinin etkinliği ve adaleti ile gelir faktörlerinin gönüllü vergi uyumu üzerinde istatistiksel olarak anlamlı bir etkisinin bulunmadığı ortaya konmuştur.

Sonuçlara göre mükellefin en yakınında diğer bir ifadeyle referans grubundaki kişilerin vergiyi doğru beyan etme, zamanında ödeme vb. konularda vergi uyumunun olumsuz veya yetersiz olması ve bunun referans grup tarafından onaylanması o kişinin vergi uyumunu olumsuz olarak etkileyebilecektir. Benzer şekilde bireyin yaşadığı toplumdaki referans aldığı gruplar (sanatçılar, şarkıcılar, sporcular vb.) vergi kaçırmayı benimsiyor/benimsemiyor, mükellef olarak görevlerini yerine getiriyor/getirmiyorsa bunu gören birey de aynı eğilimi gösterebilecek ve bunların sonucu olarak mükellefin vergiye gönüllü uyumu olumlu/olumsuz olarak etkilenebilecektir. Çalışmada sık sık uygulanan vergi aflarının mükellefin vergiye gönüllü uyumunu negatif yönde etkilediği sonucuna varılmıştır. Vergi aflarının çıkarılma sıklığı arttıkça mükellefler tarafından yeni bir af çıkarılma beklentisi oluşacağı için gönüllü uyum olumsuz etkilenebilecektir. Çalışmanın sonucuna göre vergi oranları da vergi uyumu üzerinde negatif yönde anlamlı bir etkiye sahiptir. Vergi oranları arttıkça vergiye gönüllü uyum olumsuz etkilenmektedir. Vergi yükü artacak olan mükellefler vergi kaçırma veya vergiden kaçınma davranışı gösterebileceklerdir. Bu durum beraberinde kayıt dışı ekonomik faaliyetlere sebep olabilecektir. Bu konuda vergi oranlarının optimal seviyede kalması, mükellefler tarafından tepkiyle karşılanmaması adına büyük önem arz etmektedir. Bağımlı değişken üzerinde istatistiksel olarak anlamlı ve pozitif yönde bir etkiye sahip olan diğer bir faktör de vicdan azabı değişkenidir. Mükelleflerin duyduğu vicdan azabı arttıkça vergiye gönüllü uyum sağladıkları tespit edilmiştir. Elde edilen sonuç, literatürdeki bulguları destekler niteliktedir. 
Yapılan denetimlerin yetersizliği de vergiye gönüllü uyum üzerinde negatif yönde anlamlı bir etkiye sahiptir. Vergi denetimlerinin yeterli olmaması ile yakalanma olasılı̆̆ azalan vergi mükellefleri vergisel sorumluluklarını daha az yerine getirmekte ve bunun sonucu olarak vergiye gönüllü uyum sağlama davranışı azalmaktadır. Çalışmada dini duyarlılık ile vergiye gönüllü uyum arasında istatistiksel olarak anlamlı, pozitif ilişki tespit edilmiştir. Toplumsal yaşamda önemli bir yer edinen dini faktörler, gönüllü vergi uyumu üzerinde de etkili olmaktadır. Son olarak, vergi bilgisi vergiye uyumla pozitif ilişkilidir. Vergiler hakkında artan bilgi düzeyinin vergiye gönüllü uyumu arttırdığını, aksine daha az bilgi düzeyinin ise uyumsuzluğa neden olduğunu söylemek mümkündür. Dolayısıyla kanun koyucunun vergi mükelleflerine yönelik eğitim-öğretim hizmetleri gönüllü vergi uyumunun artmasına yardımcı olabilecektir.

Vergiye gönüllü uyum konusunun oldukça çok faktörü içermesi sebebiyle gerek mükellefler gerekse vergi idaresi açısından optimal uyum için bu faktörlerin göz önünde tutulması gerekmektedir. Çalışmada ele alınan faktörler çerçevesinde birtakım önerilerde bulunulması mümkündür. Öncelikle mükelleflerin psikolojik olarak durumları iyi bilinerek analiz edilmeli ve buna uygun bir tahsilat gerçekleştirilmelidir. Vergi afları gerektiği zaman ve gerekli mükellef grupları için çıkarılmalıdır. Aksi takdirde mükelleflerin gönüllü uyumu negatif etkilenmektedir. Vergi oranlarında yapılacak sık ve yukarı yönlü değişim de mükelleflerin vergiye olan uyumunu olumsuz etkilemektedir. Oransal düzenlemelerin belirli dönemlerde ve gerçekten gerekli olduğu zamanlarda yapılması gerekmektedir. Denetim mekanizmasının çalışma prensibinin doğru olması ve yeterli şekilde yapılması da mükellefleri caydırıcılık bağlamında oldukça önemlidir. Vergi denetim sistemi, mükelleflerin tamamını denetleyebilecek şekilde oluşturulmalıdır. Böylelikle mükellefler, kendilerine bir haksızlık yapıldığına dair kanıya varmayacaklardır. Bu durum ise vergiye gönüllü uyumu olumlu yönde etkileyebilecektir.

Verginin gerekliliği devlet tarafından kamuoyuna daha iyi bir şekilde anlatılırsa gönüllü uyum konusunda artış sağlanabilecektir. Ayrıca, vergilerin kamu hizmetlerinin bir karşılığ1 ve vatandaşlık görevi olduğu vergi eğitimi olarak öğrencilere ilköğretimde ders olarak verilmelidir. Vergi idaresinin, vergi bilgisi konusunda mükellefleri bilgilendirme araçlarında artış sağlanması ve çeşitli eğitimlerin arttırılması gönüllü uyum üzerinde olumlu bir etki doğuracaktır. Kamu spotları, kitle iletişim araçları, konferanslar aracılığıyla ve çeşitli eğitimler düzenlenerek mükellefler bilgilendirilmelidir. Sosyal ve toplumsal normlar bir bütün olarak düşünülerek vergilendirme konusunda atılacak adımlar gerçekleştirilmelidir. Neticede, vergi idaresi ile mükellefler arasındaki bağın doğru bir şekilde kurulması ve bahsi geçen hususlar üzerinde etkinlik sağlandığı takdirde gönüllü uyum pozitif bir şekilde etkilenecektir.

\section{Kaynaklar}

Adimassu, N.A. \& W. Jerene (2016), "Determinants of Voluntary Tax Compliance Behavior in Self Assessment System: Evidence from SNNPRS, Ethiopia”, International Journal of Science and Research, 5(12), 967-973. 
Akbulut, A.R. (2003), “Tax Compliance (Vergiye Gönüllü Uyum)”, Vergi Dünyası Dergisi, (266), 90-96.

Aktan, C.C. \& H. Çoban (2012), "Vergileme Ekonomisi ve Vergileme Psikolojisi Perspektiflerinden Vergiye Karşı Tutum ve Davranışları Belirleyen Faktörler", içinde: C. C. Aktan \& A. Kesik \& D. Dileyici (eds.), "Yeni”" Maliye Değişim Çağında Kamu Maliyesi: Yeni Trendler, Yeni Paradigmalar, Yeni Öğretiler, Yeni Perspektifler, Ankara: T.C. Maliye Bakanlığı Strateji Geliştirme Başkanlığı, Yayın No. 2012/420, 199-223.

Allingham, M.G. \& A. Sandmo (1972), "Income Tax Evasion: A Theoretical Analysis", Journal of Public Economics, 1, 323-338.

Alpar, R. (2011), Uygulamalı Çok Değişkenli İstatistiksel Yöntemler, 3. Baskı, Ankara: Detay Yayınc1lik.

Andreoni, J. \& B. Erard \& J. Feinstein (1998), "Tax Compliance”, Journal of Economic Literature, 36(2), 818-860.

Arlı, E. (2012), "Müşterilerin Kulaktan Kulağa İletişime Bağlı Satın Alma Kararları Üzerinde Referans Gruplarının Etkisi: Deniz Turizm İșletmeciliği Üzerine Bir Araștırma", Uluslararası Yönetim İktisat ve İsletme Dergisi, 8(17), 155-170.

Ashman, S. \& B. Fine \& S. Newman (2011), “Amnesty International? The Nature, Scale and Impact of Capital Flight from South Africa”, Journal of Southern African Studies, 37(1), 7-25.

Benk, S. \& T. Budak \& B. Yüzbaşı \& R. Mohdali (2016), "The Impact of Religiosity on Tax Compliance among Turkish Self-Employed Taxpayers", Religions, 7(37), 1-10.

Beron, K.J. \& H.V. Tauchen \& A.D. Witte (1988), “A Structural Equation Model for Tax Compliance and Auditing", NBER Working Paper No. 2556.

Büyüköztürk, Ş. (2018), Sosyal Bilimler İçin Veri Analizi El Kitabı, 24. Baskı, Ankara: Pegem Akademi Yayıncılık.

Clotfelter, C.T. (1983), "Tax Evasion and Tax Rates: An Analysis of Individual Returns", The Review of Economics and Statistics, 65(3), 363-373.

Çetin-Gerger, G. (2012), “Tax Amnesties and Tax Compliance in Turkey”, International Journal of Multidisciplinary Thought, 2(3), 107-113.

Çiçek, S. \& H.G. Çiçek \& E.A. Şahin-İpek (2019), "Vergiye Uyum Sürecinde Davranışsal Yaklaşım: Mükellef Davranışları ve Tipolojileri”, Sosyoekonomi, 27(39), 223-244.

Çokluk, Ö. (2010), "Lojistik Regresyon Analizi: Kavram ve Uygulama", Kuram ve Uygulamada Ë̆itim Bilimleri Dergisi, 10(3), 1357-1407.

Çolak, E. (2002), "Koşullu ve Sınırlandırılmış Lojistik Regresyon Yöntemlerinin Karşılaştırılması ve Bir Uygulama”, Yayınlanmamış Yüksek Lisans Tezi, Eskişehir: Osmangazi Üniversitesi.

Damajanti, A. \& A. Karim (2017), "Effect of Tax Knowledge on Individual Taxpayers Compliance", Economics \& Business Solutions Journal, 1(1), 1-19.

Deyganto, K.O. (2018), "Factors Influencing Taxpayers' Voluntary Compliance Attitude with Tax System: Evidence from Gedeo Zone of Southern Ethiopia", Universal Journal of Accounting and Finance, 6(3), 92-107.

Djajanti, A. (2020), "Developing the Voluntary Taxpayer Compliance: The Scale of the Tax Authority's Power, Trust and the Fairness of the Tax System", Indonesian Journal of Business and Entrepreneurship, 6(1), 86-96. 
Tabakan, G. \& O. Avc1 (2021), "Vergiye Gönüllü Uyumu Etkileyen Faktörlerin Lojistik Regresyon Analizi ile Belirlenmesi”, Sosyoekonomi, 29(48), 541-561.

Dolbun, M. (2019), “Vergi Uyumu Kapsamında Kurumlar Vergisi Mükelleflerinin Davranışları”, Yayımlanmamış Doktora Tezi, İstanbul: İstanbul Üniversitesi.

Dubin, J.A. (2007), "Criminal Investigation Enforcement Activities and Taxpayer Noncompliance", Public Finance Review, 35(4), 500-529.

Eisenhauer, J.G. (2008), "Ethical Preferences, Risk Aversion, and Taxpayer Behaviour", The Journal of Socio-Economics, 37(1), 45-63.

Eiya, O. \& O.J. Ilaboya \& A.F. Okoye (2016), "Religiosity and Tax Compliance: Empirical Evidence from Nigeria", Igbinedion University Journal of Accounting, 1, $27-41$.

Erdem, M. \& D. Şenyüz \& İ. Tatlığlu (2020), Kamu Maliyesi, Gözden Geçirilmiş 15. Baskı, Bursa: Ekin Basım Yayın Dağıtım.

Fauziati, P. \& A.F. Minovia \& R.Y. Muslim \& R. Nasrah (2016), "The Impact of Tax Knowledge on Tax Compliance Case Study in Kota Padang, Indonesia", Journal of Advanced Research in Business and Management Studies, 2(1), 22-30.

Feldstein, M. (1995), “The Effect of Marginal Tax Rates on Taxable Income: A Panel Study of the 1986 Tax Reform Act”, Journal of Political Economy, 103(3), 551-572.

Fisman, R. \& S-J. Wei (2004), “Tax Rates and Tax Evasion: Evidence from "Missing Imports" in China", Journal of Political Economy, 112(2), 471-496.

Garcia-Valinas, M.A. \& A. Macintyre \& B. Torgler (2012), "Volunteering, Pro-Environmental Attitudes and Norms", The Journal of Socio-Economics, 41(4), 455-467.

Gelir İdaresi Başkanlığı (2007), Mükellef Hizmetleri Temel Teknikleri Katılımcı Ders Kitabı, Ankara: Mükellef Hizmetleri Daire Başkanlığı, Yayın No: 40.

Goldacre, M.J. \& K. Taylor \& T.W. Lambert (2010), "Views of Junior Doctors About Whether Their Medical School Prepared Them Well For Work: Questionnaire Surveys", BMC Medical Eduction, 10(78), 1-9.

Graetz, M.J. \& L.L. Wilde (1985), “The Economics of Tax Compliance: Fact and Fantasy”, National Tax Journal, 38(3), 355-363.

Grasmick, H.G. \& W.J. Scott (1982), "Tax Evasion and Mechanisms of Social Control: A Comparison with Grand and Petty Theft", Journal of Economic Psychology, 2(3), 213230.

Güngör-Göksu, G. \& K. İzgi-Şahpaz (2015), “Comparison of Tax Morale of Turkish and Spanish Higher Education Students: The Samples of Sakarya University and the Universty of Zaragoza", Procedia-Social and Behavioral Sciences, (186), 222-230.

Gürler-Hazman, G. (2009), "Vergi Bilincini Etkileyen Muhtemel Dişsal Etkenlerin Lojistik Regresyon Analizi ile Tespiti”, Akademik Incelemeler Dergisi, 4(1), 53-71.

İpek, S. \& İ. Kaynar (2009), "Vergiye Gönüllü Uyum Konusunda Çanakkale İline Yönelik Ampirik Bir Çalışma", Yönetim ve Ekonomi Dergisi, 16(1), 173-190.

İyit, N. \& A. Genç (2005), "Lojistik Regresyon Analizi Yardımıyla Denekte Menopoz Evresine Geçişe İlişkin Bir Sınıflandırma Modelinin Elde Edilmesi”, Selçuk Üniversitesi Fen Edebiyat Fakültesi Fen Dergisi, (25), 19-27.

Jackson, B.R. \& P.R. Jaouen (1989), "Influencing Taxpayer Compliance through Sanction Threat or Appeals to Conscience", Advances in Taxation, (2), 131-147.

James, S. \& C. Alley (2004), "Tax Compliance, Self-Assessment and Tax Administration”, Journal of Finance and Management in Public Services, 2(2), 27-42. 
Kirchler, E. \& E. Hoelzl \& I. Wahl (2008), "Enforced Versus Voluntary Tax Compliance: The "Slippery Slope" Framework", Journal of Economic Psychology, 29(2), 210-225.

Kirchmaier, I. \& J. Prüfer \& S.T. Trautmann (2018), "Religion, Moral Attitudes and Economic Behavior", Journal of Economic Behavior and Organization, (148), 282-300.

Kubar, Y. \& G. Kıral (2019), "Lise Öğrencilerinin Şiddet Algısı Üzerine Bir Araştırma: Elâzı̆̆ Merkez İlçe Örneği”, ÇÜ Sosyal Bilimler Enstitüsü Dergisi, 28(2), 354-374.

Kumluca, İ. (2003), "Vergiye Gönüllü Uyumu Etkileyen Faktörler”, Vergi Sorunları Dergisi, (180), 91-97.

Lemoine, J. \& C. Roland-Levy (2013), “Are Taxpayers, Who Pay Their Taxes, All Cooperative Citizens?”, Citizenship Teaching \& Learning, 8(2), 195-213.

Lerman, A.H. (1986), "Tax Amnesty: The Federal Perspective”, National Tax Journal, 39(3), 325332.

Luitel, H.S. \& R.S. Sobel (2007), “The Revenue Impact of Repeated Tax Amnesties”, Public Budgeting \& Finance, 27(3), 19-38.

Mas'ud, A. \& A.A. Aliyu \& E-M.J. Gambo (2014), "Tax Rate and Tax Compliance in Africa", European Journal of Accounting Auditing and Finance Research, 2(3), 22-30.

Mikesell, J.L. \& J.M. Ross (2012), "Fast Money? The Contribution of State Tax Amnesties to Public Revenue Systems", National Tax Journal, 65(3), 529-562.

Mohdali, R. \& J. Pope (2014), “The Influence of Religiosity on Taxpayers' Compliance Attitudes Empiricial Evidence from a Mixed-Methods Study in Malaysia”, Accounting Research Journal, 27(1), 71-91.

Newman, W. \& M. Nokhu (2018), "Evaluating the Impact of Tax Knowledge on Tax Compliance among Small Medium Enterprises in a Developing Country", Academy of Accounting and Financial Studies Journal, 22(6), 1-14.

Niu, Y. (2011), "Tax Audit Impact on Voluntary Compliance", Journal of Economic and Social Measurement, 36(4), 237-251.

Okoye, F. (2019), “The Influence of Tax Amnesty Programme on Tax Compliance in Nigeria: The Moderating Role of Political Trust", Journal of Accounting and Taxation, 11(7), 120129.

Ömür, Ö.M. \& U. Bellikli (2019), "Vergiye Gönüllü Uyumu Etkileyen Sosyal Faktörlerin Vergi Tahsilat Oranları ile İlişkisi: Doğu Karadeniz Bölgesindeki Seçilmiş İllerde Bir Araştırma", Manisa Celal Bayar Üniversitesi Sosyal Bilimler Dergisi, 17(2), 241-265.

Özdamar, K. (2004), Paket Programlar ile İstatistiksel Veri Analizi 1, Eskişehir: Kaan Kitabevi.

Öz-Yalama, G. \& E. Gümüş (2013), "Vergi Kaçırma Eğilimini Etkileyen Faktörler: Eskişehir'den Bulgular”, Uluslararası Yönetim İktisat ve İsletme Dergisi, 9(20), 77-97.

Palil, M.R. vd. (2013), "The Perception of Tax Payers on Tax Knowledge and Tax Education with Level of Tax Compliance: A Study the Influences of Religiosity", ASEAN Journal of Economics, Management and Acoounting, 1(1), 118-129.

Plumley, A.H. (2002), "The Impact of the IRS on Voluntary Tax Compliance: Preliminary Empirical Results", National Tax Association Proceedings, 95, 355-363.

Rajagukguk, S.M. \& F. Sulistianti (2012), "Religiousity Over Law and Tax Compliance”, Prosiding Seminar Nasional, 1-6. 
Saad, N. (2014), “Tax Knowledge, Tax Complexity and Tax Compliance: Taxpayers' View”, Procedia-Social and Behavioral Sciences, (109), 1069-1075.

Scott, W.J. \& H.G. Grasmick (1981), "Deterrence and Income Tax Cheating: Testing Interaction Hypotheses in Utilitarian Theories", The Journal of Applied Behavioral Science, 17(3), 395-408.

Serim, N. (2015), “Gönüllü Vergi Uyumunu Arttırmada Kamu Otoritesinin Düzenleyici Rolünün ve Mükellef Çevresinin Önemi: Sıralı Probit Model Yaklaşımı”, Afyon Kocatepe Üniversitesi İktisadi ve İdari Bilimler Fakültesi Dergisi, 17(1), 141-156.

Sigle, M. vd. (2018), "Corporate Tax Compliance: Is a Change Towards Trust-Based Tax Strategies Justified?", Journal of International Accounting, Auditing and Taxation, 32, 3-16.

Song, Y-D \& T. E. Yarbrough (1978), “Tax Ethics and Taxpayer Attitudes: A Survey”, Public Administration Review, 38(5), 442-452.

Tekin, A. \& Ö. Sökmen-Gürçam (2017), "Vergi Affı Uygulamalarının Vergiye Gönüllü Uyum ile İlişkisi: Iğdır İli Üzerine Bir Araştırma", İnsan ve Toplum Bilimleri Araştırmaları Dergisi, 6(6), 116-126.

Toraman, C. \& C. Karaca (2016), "Kimya Endüstrisinde Faaliyet Gösteren Firmalar Üzerinde Mali Başarısızlık Tahmini: Borsa İstanbul'da Bir Uygulama", Muhasebe ve Finansman Dergisi, 111-127.

Torgler, B. \& C.A. Schaltegger (2005), “Tax Amnesties and Political Participation”, Public Finance Review, 33(3), 403-431.

Torgler, B. (2002), "Speaking to Theorists and Searching for Facts: Tax Morale and Tax Compliance in Experiments", Journal of Economic Surveys, 16(5), 657-683.

Torgler, B. (2004), "Cross-Culture Comparison of Tax Morale and Tax Compliance: Evidence from Costa Rica and Switzerland", International Journal of Comparative Sociology, 45(1-2), 17-43.

Tuay, E. \& İ. Güvenç (2007), Türkiye'de Mükelleflerin Vergiye Bakışı, Gelir İdaresi Başkanlığı, Mükellef Hizmetleri Daire Başkanlığı, Yayın No: 51.

Türkay, İ. (2019), "Vergi Bilinci/Vergi Ahlak1/Vergiye Gönüllü Uyum ve Vergiye Gönüllü Uyumu Etkileyen Faktörler”, Vergi Raporu Dergisi, (232), 161-203.

Uyanık, A. (2019), "Vergi Bilinci ve Vergiye Gönüllü Uyumun Vergi Gelirlerine Etkilerinin Değerlendirilmesi", Maliye Dergisi, (177), 354-386.

Yorubulut, S. \& F. Erdugan (2018), "Hastanenin Tekrar Tercih Edilebilirliğinin Lojistik Regresyon ile İncelenmesi”, Turkish Journal of Clinics and Laboratory, 9(3), 185-190.

Yurdadoğ, V. \& R. Gökbunar \& B. Tunçay (2016), "Vergi Uyumunu Belirleyen Faktörlere Genel Bir Bakış", Yönetim ve Ekonomi: Celal Bayar Üniversitesi İktisadi ve İdari Bilimler Fakültesi Dergisi, 23(3), 805-816. 